Int. J. Electrochem. Sci., 14 (2019) $1093-1106$

International Journal of

ELECTROCHEMICAL

SCIENCE

www.electrochemsci.org

\title{
Catalytic Activity of Ni-YSZ composite as Anode for Methane Oxidation in Solid Oxide Fuel Cells
}

\author{
Yanting Tian ${ }^{1, *}$, Zhe L̈̈ $^{2,}$, Xiang Guo ${ }^{1}$, Pingping $W u^{l}$ \\ ${ }^{1}$ College of Physics and Optoelectronics, Taiyuan University of Technology, Taiyuan 030024, China \\ ${ }^{2}$ Department of Physics, Harbin Institute of Technology, Harbin 150001, China \\ *E-mail: yanting_005@163.com, 1vzhe@,hit.edu.cn
}

doi: $10.20964 / 2019.02 .48$

Received: 4 September 2018 / Accepted: 12 November 2018 / Published: 5 January 2019

\begin{abstract}
Natural gas has been exploited as an available energy source for solid oxide fuel cells in recent years. However, the problem of carbon deposition that forms on nickel-based anodes by using direct methane results in performance failure of cells. It is well known that the catalytic partial oxidation of methane is a good solution to suppress carbon formation. Herein, we present an investigation of the catalytic activity of $\mathrm{Ni} / \mathrm{YSZ}$ cermet anodes as a function of the $\mathrm{CH}_{4} / \mathrm{O}_{2}$ flow rate ratio $\left(1 \leq R_{\text {in }} \leq 5\right)$. The behavior of methane catalytic activity was characterized using mass spectrometry (MS) and temperatureprogrammed oxidation (TPO). The catalytic activity of methane oxidation at $700{ }^{\circ} \mathrm{C}$ showed that $\mathrm{Ni}$ oxidation occurred at $R_{\text {in }} \leq 1.67$. A basic equilibrium to prevent carbon deposition and Ni oxidation occurred at $R_{\text {in }}=2.5$, which exhibited the best activity among the Ni/YSZ electrodes. Through the electrochemical measurements and impedance spectroscopy analysis of the cell, it was proved that the cell possessed the lowest ohmic resistance and optimized output performance at $R_{\text {in }}=2.5$. In addition, a stable cell operation at $0.9 \mathrm{~V}$ was guaranteed without serious degradation.
\end{abstract}

Keywords: Solid Oxide Fuel Cells, Catalytic Activity, $\mathrm{CH}_{4} / \mathrm{O}_{2}$ Ratio, Ni-YSZ Anode, Partial Oxidation

\section{FULL TEXT}

(C) 2019 The Authors. Published by ESG (www.electrochemsci.org). This article is an open access article distributed under the terms and conditions of the Creative Commons Attribution license (http://creativecommons.org/licenses/by/4.0/). 